\title{
A Motivação em Orquestras Jovens e Profissionais
}

\author{
Joseane Raquel Porfirio (IC), Carlos Fernando Fiorini (PQ)
}

\section{Resumo}

Este trabalho propõe uma pesquisa acerca de fatores motivacionais que podem influenciar o desenvolvimento técnico e musical de estudantes de música no ambiente de uma orquestra jovem e de músicos experientes em orquestras profissionais. Através da incorporação de teorias estabelecidas no campo da motivação humana dentro da área da educação musical, pretende buscar possíveis explicações para a motivação dos músicos e seu engajamento em atividades musicais nas orquestras.

Palavras Chave: Motivação, orquestra, ensino musical.

\section{Introdução}

De acordo com Boruchovitch (2009), Bzuneck (2009) e Guimarães (2010) a motivação leva a uma escolha, faz iniciar um comportamento direcionado a um objetivo e, além disso, assegura sua persistência perante fracassos e outros motivos concorrentes que tentam a pessoa a interromper ou a mudar o curso de ação ${ }^{1}$, assim, partindo desta premissa, esta pesquisa propõe, a partir do uso de algumas teorias e modelos motivacionais, estudar quais fatores externos podem influenciar a motivação dos músicos durante ensaios e apresentações.

\section{Resultados e Discussão}

Além do estudo de teorias estabelecidas no campo da motivação humana e educacional, foi elaborado para esta pesquisa um questionário direcionado a regentes, estudantes de música e músicos profissionais. Neste questionário foram abordadas questões referentes aos fatores que podem influenciar a motivação do músico/estudante. A pesquisa mostrou que, apesar de possuírem características e objetivos diferenciados, pois, para uma orquestra jovem interessa não somente o resultado final, mas também o aprendizado do processo, ambos os grupos são afetados em sua motivação de forma bastante similar. De acordo com as respostas dos entrevistados, fatores como 0 ambiente psicológico e a preparação e dinâmica do ensaio por parte do regente interferem muito na motivação dos integrantes das orquestras jovens e profissionais. Por outro lado, o público presente nos concertos e os locais de apresentação não se mostraram tão relevantes para esses músicos.

\section{Conclusões}

A motivação dos músicos em relação ao trabalho a ser realizado em uma orquestra está relacionada a um conjunto de fatores materiais e psicológicos similares, não importando se os músicos em questão possuem larga experiência na área ou se são estudantes de música

\section{Agradecimentos}

Ao Prof. Dr. Carlos Fernando Fiorini pela orientação e atenção durante a realização dessa pesquisa.

\footnotetext{
${ }^{1}$ Stipek, 1996; Pintrch \& Schunk 1996; citado por Bzuneck, 2009, p.9-10.
} 